\title{
Reply: Long-term Follow-up of Patients with Metastatic Differentiated Thyroid Carcinoma
}

\author{
Tada Yipintsoi · Teerapon Premprabha • \\ Alan Geater
}

Published online: 8 June 2010

(C) Société Internationale de Chirurgie 2010

Bertagna and Giubbini commented on their longer survival (10-year survival of $72 \%)$ of their 32 patients with welldifferentiated thyroid cancer with bone spread [1] (probably some with lung and/or lymph nodes spread) compared with our report of $34 \%$ [2]. Our low survival belonged to a specific bone spread, i.e., those presenting with pathological fracture. In contrast, distant metastases, excluding aerodigestive tract or pathological bone fractures, showed a much higher survival.

\section{References}

1. Bertagna F, Giubbini R (2010) Long-term follow-up of patients with metastatic differentiated thyroid carcinoma [letter]. World $\mathrm{J}$ Surg. doi:10.1007/s00268-010-0472-x

2. Yipintsoi T, Premprabha T, Geater A et al (2010) Mortality-related factors in 1056 radioiodine-treated patients with well-differentiated thyroid cancer in southern Thailand. World J Surg 34:230236

T. Yipintsoi

Department of Medicine, Prince of Songkla University,

Songkhla, Thailand

T. Premprabha $(\varangle)$

Department of Radiology, Prince of Songkla University,

Songkhla, Thailand

e-mail: pteerapo@medicine.psu.ac.th

\section{A. Geater}

Epidemiology Unit, Prince of Songkla University, Songkhla,

Thailand 